\title{
КОМПЛЕКСНЫЙ ПОДХОД К СКРИНИНГУ \\ IN VITRO И IN SILICO - СТРАТЕГИЯ ПОИСКА НОВЫХ ПРОТИВОВИРУСНЫХ СОЕДИНЕНИЙ
}

\author{
Д.И. Осолодкин ${ }^{1,2,3}$, А.А. Никитина, ${ }^{1,2}$, А.А. Орлов ${ }^{1,2}$, В.И. Уварова', \\ А.Д. Фомина ${ }^{1,2}$, В.С. Фроленко ${ }^{1,3}$, Е.В. Хватов', Л.И. Козловская ${ }^{1,3}$, \\ А.А. Ишмухаметов ${ }^{1,3}$, А.М. Егоров ${ }^{1,2}$ \\ ${ }^{1}$ ФГАНУ «ФНЦИРИП им. М.П. Чумакова РАН» (Институт полиомиелита), \\ 108819, Россия, Москва, поселение Московский, пос. Института полиомиелита, д. 8, стр. 1. \\ ${ }^{2}$ Химический факультет Московского государственного университета \\ им. М.В. Ломоносова, 119991, Россия, Москва, Ленинские горы, 1 стр. 3. \\ ${ }^{3}$ Институт трансляционной медицины и биотехнологии, ФГАОУ ВО Первый МГМУ \\ им. И.М. Сеченова Минздрава России (Сеченовский Университет), \\ 119991, Россия, Москва, Нахимовский проспект, 45.
}

DOI: 10.19163/MedChemRussia2021-2021-216

E-mail: osolodkin_di@chumakovs.su

Вирусные инфекции представляют собой постоянно существующую угрозу общественному здоровью и обладают потенциалом внезапного возникновения и распространения до пандемических масштабов. Применение противовирусных препаратов на основе малых молекул является важнейшей стратегией профилактики и лечения вирусных инфекций, дополняющей либо заменяющей программы вакцинации. Сочетание фенотипического и мишень-ориентированного скрининга in vitro $и$ in silico позволяет достичь максимальной эффективности на ранних стадиях разработки противовирусных препаратов. В докладе рассматриваются примеры применения этой стратегии.

На основе анализа больших объёмов общедоступных данных о противовирусной активности малых молекул методами машинного обучения [1-4] нами выявлены новые хемотипы ингибиторов репродукции вируса клещевого энцефалита [4-8] и коронавируса SARS-CoV-2 [3,7], активность которых подтверждена экспериментально. Разработаны методы исследования взаимодействия малых молекул с вирусными белковыми мишенями (белок оболочки Е и метилтрансфераза ВKЭ, протеаза 3CL pro SARS-CoV-2 и др.), применимые для изучения механизмов действия ингибиторов репродукции вирусов, а также для мишень-ориентированного скрининга. Методами структурной вирусологии ведётся исследование строения лиганд-белковых комплексов наиболее перспективных соединений для дальнейшей оптимизации.

\section{Литература}

[1] A.A. Nikitina et al., Database. 2019, 2019, bay139.

[2] E.A. Sosnina et al., ACS Omega. 2020, 5, 15039-15051.

[3] D. Horvath et al., Molecular Informatics. 2020, 39, 2000080.

[4] A.A. Orlov et al., Molecular Informatics. 2019, 38, 1800166.

[5] D. Ruzek et al., Antiviral Research. 2019, 164, 23-51.

[6] D.A. Vasilenko et al., Bioorganic Chemistry. 2019, 87, 629-637.

[7] L.I. Kozlovskaya et al., European Journal of Medicinal Chemistry. 2021, 220, 113467.

[8] E.V. Dueva et al., Antiviral Chemistry and Chemotherapy. 2020, 28, 2040206620943462. 